\title{
Root adaptation and ion selectivity affects the nutritional value of salt-stressed hydroponically grown baby-leaf Nasturtium officinale and Lactuca sativa
}

Juan A. Fernández ${ }^{\mathrm{a}}$, Diana Niñirola ${ }^{\mathrm{a}}$, Jesús Ochoa ${ }^{\mathrm{a}}$, Francesco Orsini ${ }^{\mathrm{b}}$, Giuseppina Pennisi ${ }^{\mathrm{b}, \mathrm{c}}$, Giorgio Gianquinto $^{\mathrm{b}}$, Catalina Egea-Gilabert ${ }^{d}$

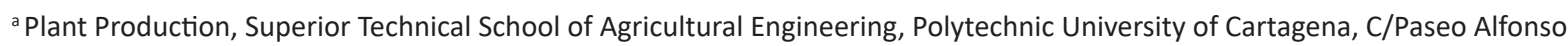
XIII 48, 30203 Cartagena, Spain

${ }^{\mathrm{b}}$ Research Centre in Urban Environment for Agriculture and Biodiversity, Agricultural Sciences Department, Alma Mater Studiorum University of Bologna, Viale Fanin, 44, 40127, Bologna, Italy

' Department of Agriculture, Forest and Food Sciences, University of Turin, Largo Paolo Braccini, 2, 10095 Grugliasco (Torino), Italy

${ }^{\mathrm{d}}$ Agricultural Science and Technology, Superior Technical School of Agricultural Engineering, Polytechnic University of Cartagena, C/Paseo Alfonso XIII 48, 30203 Cartagena, Spain

email: f.orsini@unibo.it

\begin{abstract}
The response of watercress (Nasturtium officinale L.) to salinity has been scarcely addressed in literature despite its growing importance in the baby-leaf market and its wide cultivation in salt-affected agricultural regions. This work evaluates the effect of salinity $\left(2.5,5\right.$ and $\left.10 \mathrm{dS} \mathrm{m}^{-1}\right)$ on productive and quality features of watercress compared with another crop widely cultivated for the baby-leaf sector (lettuce, Lactuca sativa). In watercress, a linear relationship $\left(\mathrm{R}^{2}=0.75\right)$ was observed between yield decrease and $\mathrm{Cl}^{-}$accumulation in leaves, whereas yield was not affected by salinity in lettuce. $\mathrm{NaCl}$ application increased $\mathrm{Na}^{+}$accumulation at the expense of $\mathrm{Ca}^{2+}$ uptake in the leaf tissues of both crops, but also of $\mathrm{K}^{+}$in watercress. Health-related features were improved by salinity (e.g. increased phenolics and reduced nitrates), especially in watercress, with limited sensorial quality evaluation effects.
\end{abstract}

Key words: phenolics, nitrates, salinity, quality, ready-to-eat

\section{Introduction}

Increased health consciousness and growing interest in the role of food for maintaining and improving human well-being have resulted in changes in dietary habits and are important factors in the increased diffusion of minimally processed or fresh-cut leafy vegetables (Soliva-Fortuny and Martìn-Belloso 2003, Brecht et al. 2004). Leafy vegetables are widely considered as a fundamental source of vitamins, minerals, fibre, and other phytochemicals with health-promoting effects, such as carotenoids and polyphenols (Kimura et al. 2003). Nonetheless, their nutritional quality can be influenced by several factors during the growing season or as a result of post-harvest processes (Kader 2008), leading to the biosynthesis and accumulation of antinutritional and toxic principles such as nitrate, oxalate and saponins (Amr and Hadidi 2001). Plants exposed to environmental stresses have been shown to increase the levels of beneficial compounds they contain (e.g. antioxidants), and to enhance specific quality features, such as a reduction in the leaf nitrate content (Pérez-López et al. 2015). The use of soilless cultivation systems such as the floating system allows clean and safe vegetables to be obtained for the processing industry. Moreover, being relatively cheap, this technique can be easily implemented at commercial level and promotes efficient water use (Rodríguez-Hidalgo et al. 2009). Indeed, its application for growing fresh-cut vegetables has increased steadily in recent years (Tomasi et al. 2015), only inhibited by water quality and availability (Acosta et al. 2011). In recent years, an increase in the application of intensive agricultural practises (including the wide use of fertilizers) and the frequency of extreme droughts have increased salinization of the available irrigation water (Perez-Sirvent et al. 2003, Ekholm et al. 2007).

Watercress (Nasturtium officinale R. Br.), a member of the Brassicaceae family, is native of Europe, northern Africa and temperate and tropical parts of Asia and Europe, and it is naturalized elsewhere (GRIN 2012). It is normally consumed as a vegetable in fresh salads. Several studies have reported the beneficial effects to human health of consuming watercress; these include anticancer effects (Verhoeven et al. 1997), reduced lymphocyte DNA damage and alterations of the blood antioxidant status in healthy adults (Gill et al. 2007), as well a well-documented 
diabetes prevention effect (Shahrokhi et al. 2009). However, knowledge of the tolerance to salt stress of this species is limited, although Kaddour et al. (2013) reported that at up to $100 \mathrm{mM} \mathrm{NaCl}$, watercress responses to salt include maintained growth, osmotic adjustment via $\mathrm{Na}^{+}$and $\mathrm{Cl}^{-}$, and high $\mathrm{K}^{+}$: $\mathrm{Na}^{+}$selectivity. In the same way, natural antioxidant defence compounds (vitamin C, carotenoids and polyphenols) increased when plants were grown at up to $100 \mathrm{mM} \mathrm{NaCl}$. However, despite its generally high concentrations in plant tissue, there are no reports on the potential effect of salinity for reducing the nitrate content of watercress (Pignata et al. 2016). This contrasts with the several studies that highlight decreases in the nitrate content of lettuce (Lactuca sativa L.) as salinity increases (Scuderi et al. 2011, Neocleus et al. 2014).

In view of the above, the aim of the present work was to compare the responses of one variety of watercress and one variety of lettuce to different salinity conditions in terms of plant growth performances, mineral composition and some aspects of nutritional quality.

\section{Materials and methods Plant material and growth conditions}

The experiments were conducted at the "Tomás Ferro" Experimental Agro-Food Station, Technical University of Cartagena (UPCT; lat. $37^{\circ} 41^{\prime} \mathrm{N}$; long. $0^{\circ} 57^{\prime} \mathrm{W}$ ). The commercial cultivar of watercress (Nasturtium officinale R. Br.) "Large leaf" (Tozer Seeds Co., Cobham, U.K.) and of baby leaf lettuce (Lactuca sativa) cv. Ganeria (green batavia) (Rijk Zwaan, De Lier, Netherlands) were cultivated in a floating system in an unheated greenhouse covered with a thermal low density polyethylene film of $200 \mu$ thick. Two crop cycles (winter and spring) were carried out with sowings on 20 February 2012 (lettuce) and 27 February 2012 (watercress) and in 23 April 2012 (lettuce) and 30 April 2012 (watercress). Sowing was carried out manually into "styrofloat" trays containing peat, which were then transferred to flotation beds, floating on fresh tap water with an electrical conductivity (EC) of $1.1 \mathrm{dS} \cdot \mathrm{m}^{-1}$ and a pH of 7.8 (Niñirola et al. 2014). Aeration was provided using a blow pump connected to a perforated pipe trellis positioned at the bottom of each flotation bed. Seven days after sowing (DAS) the watercress and lettuce plants were thinned, leaving 12 (2040 plants $\mathrm{m}^{-2}$ ) and 10 (1700 plants $\mathrm{m}^{-2}$ ) plants per hole, respectively. At the same time, the tap water in the beds was replaced with a nutrient solution containing, in $\mathrm{mM}: \mathrm{NO}_{3}^{-}, 7.2 ; \mathrm{NH}_{4}^{+}, 4.8 ; \mathrm{H}_{2} \mathrm{PO}_{4}^{-}$, 2.0; $\mathrm{Ca}^{2+}, 3.2 ; \mathrm{K}^{+}, 6.0$ and $\mathrm{Mg}^{2+}, 4.0$, plus a commercial solution of microelements Nutromix 10, Biagro (2 $\left.\mathrm{mg} \mathrm{l}^{-1}\right)$ and Sequestrene (an Iron chelate, $1.5 \mathrm{mg} \mathrm{l}^{-1}$ ). The nutrient solution was adjusted to EC $2.5 \mathrm{dS} \mathrm{m}^{-1}$ and $\mathrm{pH}$ 5.6.

Sodium chloride was added to the nutrient solution for 5 days starting on DAS 13 to reach total concentrations of $9 \mathrm{mM}, 41 \mathrm{mM}$ and $91 \mathrm{mM} \mathrm{NaCl}$, thus providing three different levels of salinity $\left(2.5,5\right.$ and $\left.10 \mathrm{dS} \mathrm{m} \mathrm{m}^{-1}\right)$. Each treatment level for all the experiments was carried out in $135 \mathrm{~cm} \times 125 \mathrm{~cm} \times 20 \mathrm{~cm}$ beds located in three places inside a greenhouse. Each bed had four floating trays of $60 \mathrm{~cm} \times 41 \mathrm{~cm}$. The EC and temperature of the nutrient solution were monitored during the growing cycles using Campbell CS547 sensors (Campbell Scientific Inc., Logan, USA) in each flotation bed.

Harvesting was carried out at the same phenological stage for both cycles, that is, when three to four leaves in lettuce and seven to eight leaves in watercress had formed on each plant. Forty eight plants in watercress and forty plants in lettuce from four fissures randomly chosen from each tray were harvested for each treatment. The plants were divided randomly into two lots, one for harvest analysis and one for postharvest analysis.

\section{Analyses and determinations}

Fresh and dry matter of the aerial part and root growth were measured. Total root length and diameter were determined only in winter grown plants with a Winrhizo LA 1600 root counter (Regent Inc., Quebec, Canada). The dry matter contents were determined by drying in an oven at $50{ }^{\circ} \mathrm{C}$ until constant weight was reached. In addition, the total production (yield) was calculated. Moreover, the nitrate, potassium, calcium, sodium and chloride contents were extracted in triplicate by using $0.2 \mathrm{~g}$ of shoot dry samples per each treatment and quantified by ion chromatography (Lara et al. 2011). The total phenolic content was determined by the Folin-Ciocalteu colorimetric method (Tarazona-Díaz et al. 2011).

\section{Sensory panel test}

In the spring cycle, harvested plants were disinfected, packed in thermosealed polypropylene (PP) baskets of 1 I capacity and stored at $5{ }^{\circ} \mathrm{C}$ for 7 days, according to Niñirola et al. (2014). The sensory quality was evaluated in a tasting room after $7 \mathrm{~d}$ of cold storage by a test-trained panel consisting of 11 people (6 females and 5 males). 
Visual quality factors (overall visual quality and global quality) were scored on a 9-point hedonic scale ( $1=$ extremely poor, 3 = poor, 5 = acceptable and limit of usability, $7=$ good, and $9=$ excellent). Disorders (browning, visual dehydration, off-odours, off-colour, and off-flavours) were scored according to the following scale of damage incidence and severity: 1 = none, 2 = slight, 3 = moderate (limit of usability), 4 = severe, 5 = extreme (Tomás-Callejas et al. 2011).

\section{Statistical analysis}

A randomized complete block design with three replicates per level of salinity was used in the greenhouse in both growing seasons. Data were analysed using ANOVA and when significant differences $(p \leq 0.05)$ were observed, means were compared by Least Significant Difference (LSD).

\section{Results}

\section{Environmental conditions during the experiments}

The winter growing cycle for lettuce lasted 28 days, during which the temperatures ranged between $15.5^{\circ} \mathrm{C}$ and $23.2{ }^{\circ} \mathrm{C}$ (Table 1).

Table 1. Environmental conditions during the experiments

\begin{tabular}{lcccccc}
\hline & & Days & & Temperature & Daily light integral \\
\hline \multirow{4}{*}{ Lettuce } & & & $\operatorname{Min}\left({ }^{\circ} \mathrm{C}\right)$ & $\operatorname{Avg}\left({ }^{\circ} \mathrm{C}\right)$ & $\operatorname{Max}\left({ }^{\circ} \mathrm{C}\right)$ & $\left(\mathrm{mol} \cdot \mathrm{m}^{-2} \cdot \mathrm{s}^{-1}\right)$ \\
& Winter & 28 & 15.5 & 18.3 & 23.2 & 9.6 \\
\multirow{3}{*}{ Watercress } & Spring & 23 & 17.8 & 21.4 & 24.4 & 9.6 \\
& Winter & 27 & 12.1 & 18.0 & 23.2 & 7.3 \\
& Spring & 27 & 17.8 & 23.3 & 26.0 & 8.4 \\
\hline
\end{tabular}

The spring cycle was shorter at 23 days, with an average temperature of $21.4{ }^{\circ} \mathrm{C}$. The mean amount of photosynthetically active radiation was $9.6 \mathrm{~mol} \mathrm{~m}^{-2} \mathrm{~s}^{-1}$ in both cycles. In the case of watercress, the winter and spring growing cycles had the same duration of 27 days. Differences in the light integral were evident in watercress, being higher in spring $\left(8.4 \mathrm{~mol} \mathrm{~m}^{-2} \mathrm{~s}^{-1}\right)$ than in winter $\left(7.3 \mathrm{~mol} \mathrm{~m}^{-2} \mathrm{~s}^{-1}\right)$ (Table 1$)$. During the spring cycle, the average temperature of $23.3^{\circ} \mathrm{C}$ was higher than in the winter cycle (Table 1).

\section{Yield and plant composition in response to salinity and growing season}

Root morphology was observed to be modified as a result of salinity stress, with a general reduction in the percentage of thicker roots $\left(>0.5 \mathrm{~mm}\right.$ ) in both lettuce and watercress exposed to $5 \mathrm{dS} \mathrm{m}^{-1}$ compared with plants grown in control conditions (Fig. 1). However, when salinity was increased to $10 \mathrm{dS} \mathrm{m}^{-1}$, the percentage of thicker watercress roots was reduced further, while in lettuce a reduction in the percentage of thinner roots $(<0.5 \mathrm{~mm})$ resulted in non-significant decrease in the relative quantity of thicker roots compared with those in control conditions, restoring control mean root diameter (Fig. 1).

Lettuce yield was not affected by salinity in either growing season: mean of, $2.4 \mathrm{~kg} \mathrm{~m}^{-2}$ and $2.3 \mathrm{~kg} \mathrm{~m}^{-2}$ for the three salinity treatments in winter and spring, respectively (Fig. 2A). In watercress grown in the winter cycle, the yield was not reduced at $5 \mathrm{dS} \mathrm{m}^{-1}$ salinity (compared with the control), whereas a $37 \%$ decrease was measured at 10 $\mathrm{dS} \mathrm{m}^{-1}$. The greatest yield reduction was observed in watercress in spring causing a $28 \%$ and $46 \%$ decrease at 5

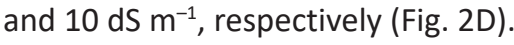

Saline stress resulted in changes in ion concentrations. The $\mathrm{Cl}^{-}$concentration, for example, increased in both lettuce and watercress as salinity increased (Figs. 2B and $2 \mathrm{E}$ ), although to a greater extent in watercress exposed to $10 \mathrm{dS} \mathrm{m}^{-1}$ salinity in spring, when it reached values of $4866 \mathrm{mg} \mathrm{kg}^{-1} \mathrm{FW}$ (Fig. 2E). The absence of any significant yield depletion in response to salinity resulted in a low regression coefficient between relative yield and $\mathrm{Cl}^{-} \mathrm{con}^{-}$ centration in lettuce (Fig. 2C), whereas high regression coefficients were observed in watercress ( $R 2=0.80$ and $\mathrm{R} 2=0.87$ in winter and spring cycles, respectively) (Fig. 2F), pointing to an inverse linear relationship between $\mathrm{Cl}^{-}$accumulation and yield. 
LETTUCE

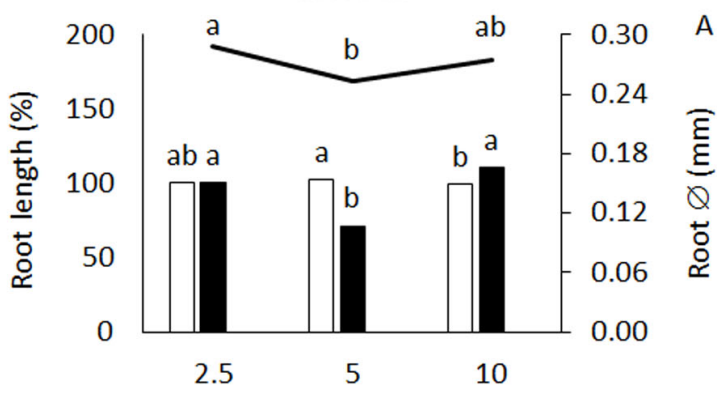

WATERCRESS

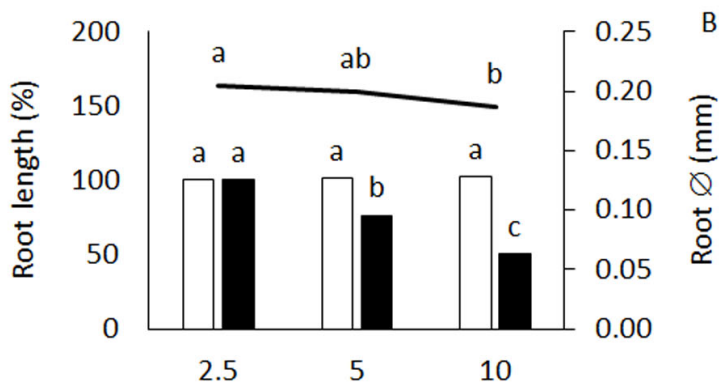

$\square<0.5 \mathrm{~mm}(\%) \square 0.5 \mathrm{~mm}(\%)$-Root diameter

Fig. 1. Effect of salinity $\left(2.5,5\right.$, and $10, \mathrm{dS} \mathrm{m}^{-1}$ ) on length of roots (\% of control value at $2.5 \mathrm{dS} \mathrm{m}^{-1}$ ) of lettuce (A) and watercress (B) plants grown in winter, according to their diameter below $0.5 \mathrm{~mm}$ (white) or above $0.5 \mathrm{~mm}$ (black), and their mean diameter $(\varnothing)$ in $\mathrm{mm}$. Different letters indicate significant differences at $p \leq 0.05$.

LETTUCE
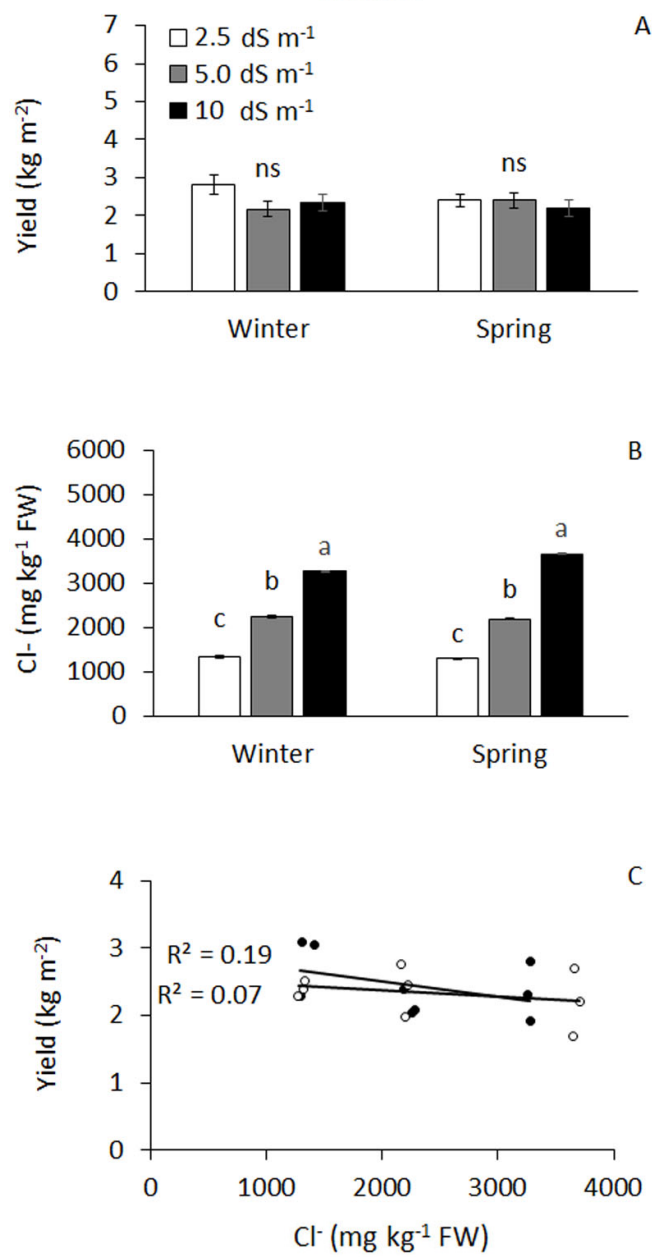

WATERCRESS
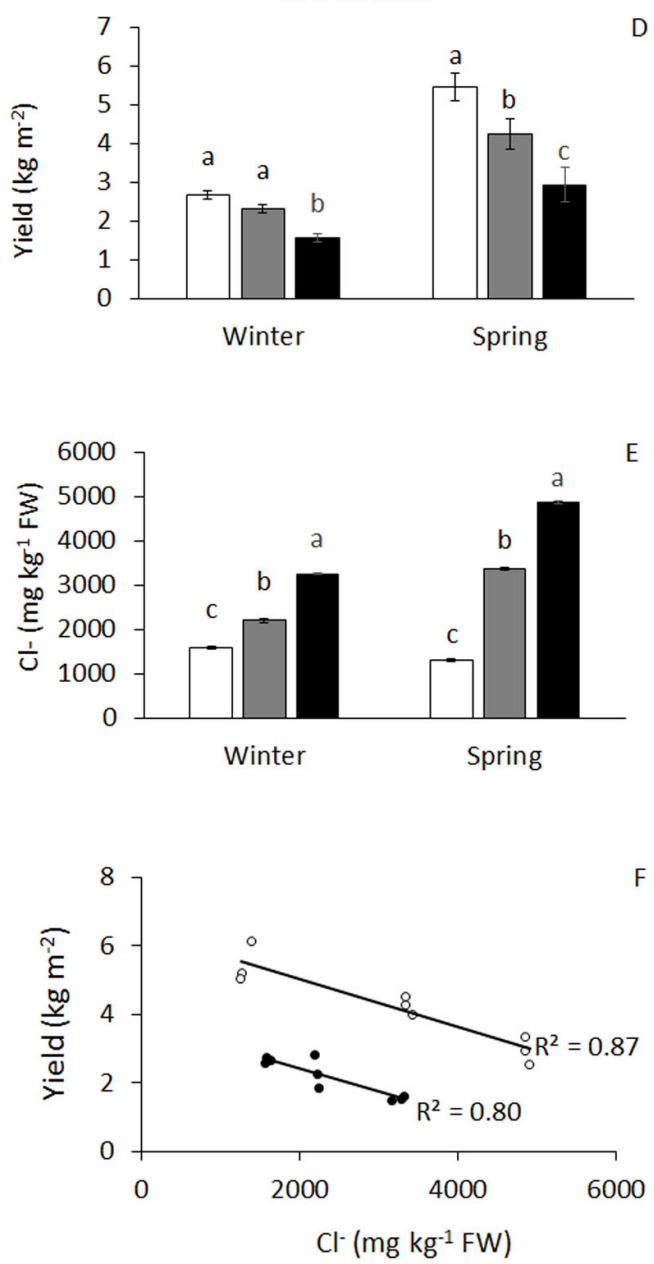

Fig. 2. Effect of salinity $\left(2.5,5\right.$ and $\left.10 \mathrm{dS} \mathrm{m}^{-1}\right)$ on yield $\left(\mathrm{kg} \mathrm{m}^{-2}\right), \mathrm{Cl}^{-}$content in leaves $\left(\mathrm{mg} \mathrm{kg}^{-1} \mathrm{FW}\right)$ and their relationship (winter, closed symbols, and spring, open symbols) in lettuce $(A, B, C)$ and watercress (D, E, F). Mean values $\pm S E$. Different letters indicate significant differences at $p \leq 0.05$, according to LSD test; ns = no significant differences. 
A significant increase in $\mathrm{Na}^{+}$accumulation in leaf tissues of both species was associated with salinity stress (Figs. 3A and 3D). The highest $\mathrm{Na}^{+}$accumulation was observed in winter cultivated watercress $\left(3028 \mathrm{mg} \mathrm{kg}^{-1} \mathrm{FW}\right)$ subject to $10 \mathrm{dS} \mathrm{m}^{-1}$ (Fig. 3D) while the lowest $\mathrm{Na}^{+}$accumulation was observed in lettuce (Fig. 3A), independently of the growing season. Both the $\mathrm{Na}^{+}: \mathrm{K}^{+}$and $\mathrm{Na}^{+}: \mathrm{Ca}^{2+}$ ratios increased with salinity in both lettuce and watercress (Figs. 3B, 3C, 3E and 3F). The highest $\mathrm{Na}^{+}: \mathrm{K}^{+}$ratio was associated with the winter cultivation of watercress (Fig. 3E) while the $\mathrm{Na}^{+}: \mathrm{Ca}^{2+}$ ratio increased most in winter cultivated lettuce (Fig. $3 \mathrm{C}$ ).

LETTUCE
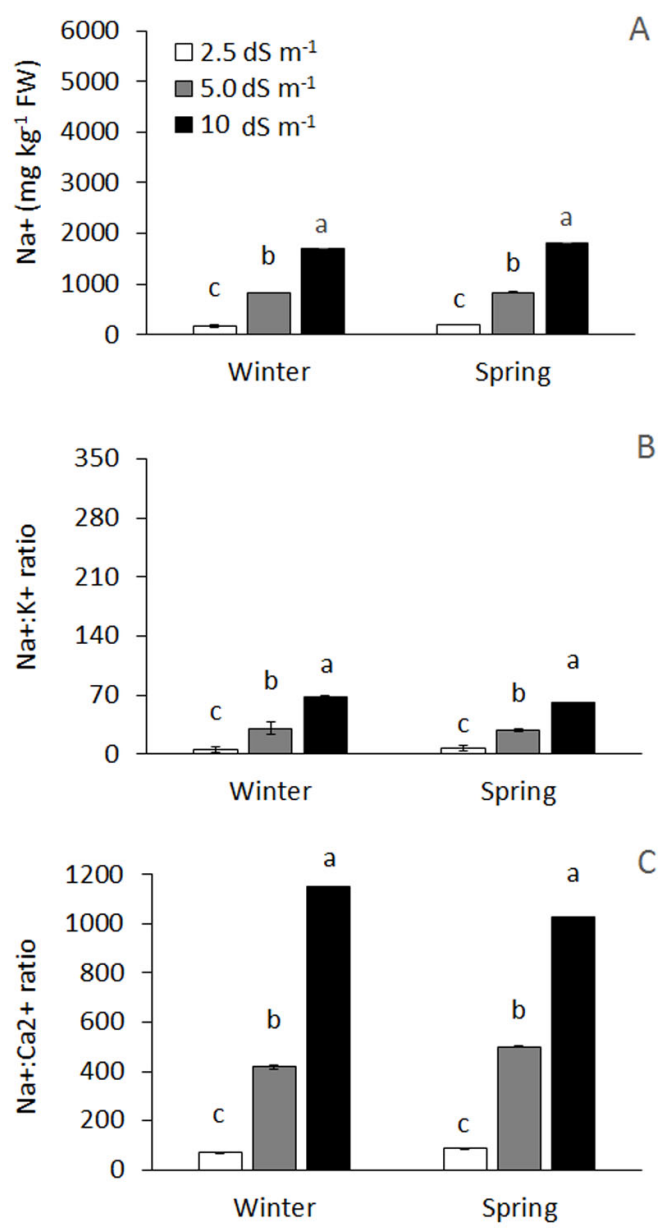

A

$B$
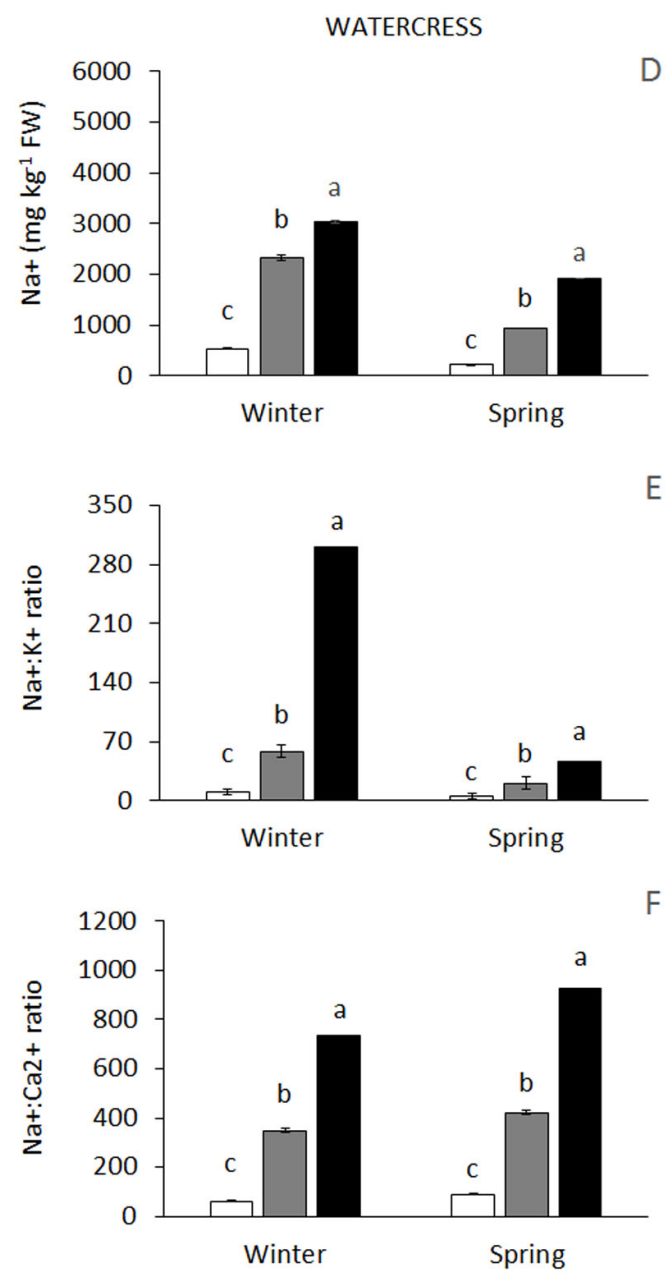

Fig. 3. Effect of salinity $\left(2.5,5\right.$, and $\left.10 \mathrm{dS} \mathrm{m}^{-1}\right)$ on $\mathrm{Na}+\left(\mathrm{mg} \mathrm{kg}^{-1} \mathrm{FW}\right), \mathrm{Na}^{+}: \mathrm{K}^{+}$ratio and $\mathrm{Na}^{+}: \mathrm{Ca}^{2+}$ ratio of lettuce $(\mathrm{A}, \mathrm{B}, \mathrm{C})$ and watercress (D, E, F). Mean values \pm SE. Different letters indicate significant differences at $p \leq 0.05$, according to LSD test.

Nitrate accumulation decreased as the level of salinity increased in both species (Figs. 4A and 4C). In lettuce, nitrate levels were highest in spring, with a mean value of $1728 \mathrm{mg} \mathrm{kg}^{-1} \mathrm{FW}$ for 2.5 and $5 \mathrm{dS} \mathrm{m}^{-1}$ of salinity, but $1583 \mathrm{mg} \mathrm{kg}^{-1} \mathrm{FW}$ in the $10 \mathrm{dS} \mathrm{m}^{-1}$ treatment (Fig. 4A). In watercress, nitrate accumulation was about 4-folds higher when the plant was grown in the winter cycle (6860 mg kg-1 FW, average for 2.5 and $5 \mathrm{dS} \mathrm{m}^{-1}$ ) as compared with plants grown in spring under $10 \mathrm{dS} \mathrm{m}^{-1}$ ) (Fig. 4C). High regression coefficients were observed between leaf chloride and nitrate concentrations in both lettuce and watercress plants in both growing seasons (Figs. 4B and 4D).

The total phenolic content of lettuce was not affected by salinity in winter, while in spring salinity stress resulted in a 33\% increase in phenolic biosynthesis (mean value of 5 and $10 \mathrm{dS} \mathrm{m}^{-1}$, Fig. 5A). In watercress grown in winter no statistical difference was found in total phenolics between 2.5 and $5 \mathrm{dS} \mathrm{m}^{-1}$ salinity levels (mean value $34 \mathrm{mg}$ CAE kg-1 FW) while $10 \mathrm{dS} \mathrm{m}^{-1}$ resulted in a 2-fold increase in the phenolic concentration in control conditions. In spring, watercress reached its highest level of total phenolics (134 mg CAE kg-1 FW) at the highest level of salinity stress (Fig. 5B). 
LETTUCE
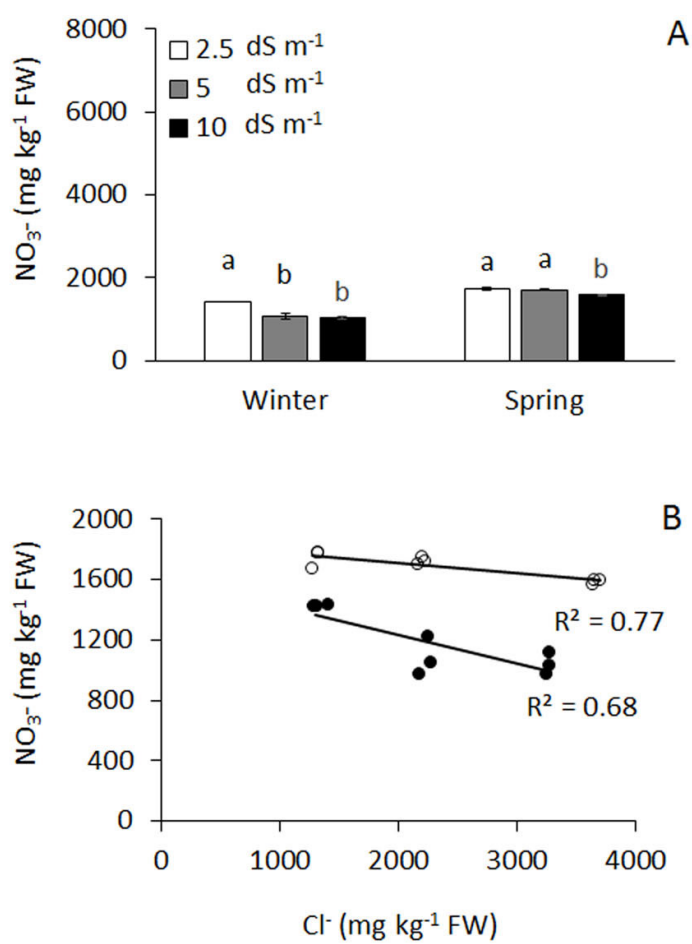

WATERCRESS
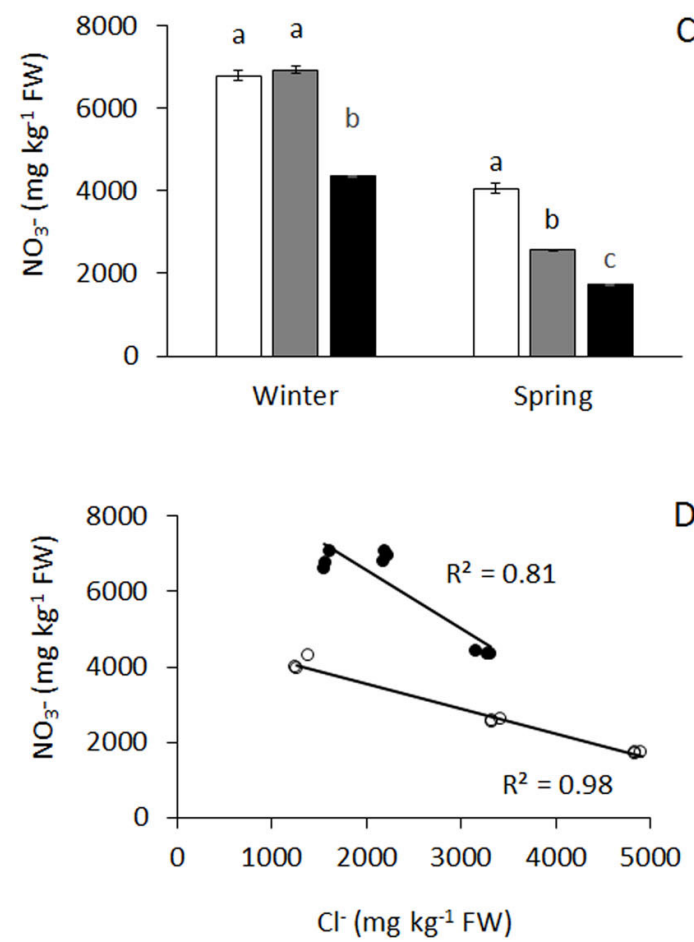

Fig. 4. Effect of salinity $\left(2.5,5\right.$ and $\left.10 \mathrm{dS} \mathrm{m}^{-1}\right)$ on leaf nitrate content $\left(\mathrm{mg} \mathrm{kg}^{-1} \mathrm{FW}\right.$, left) and linear relationships between leaf nitrate and chloride concentration in winter (closed symbols) and spring (open symbols) grown lettuce $(A, B)$ and watercress (C, D). Mean values \pm SE. Different letters indicate significant differences at $p \leq 0.05$, according to LSD test.

LETTUCE

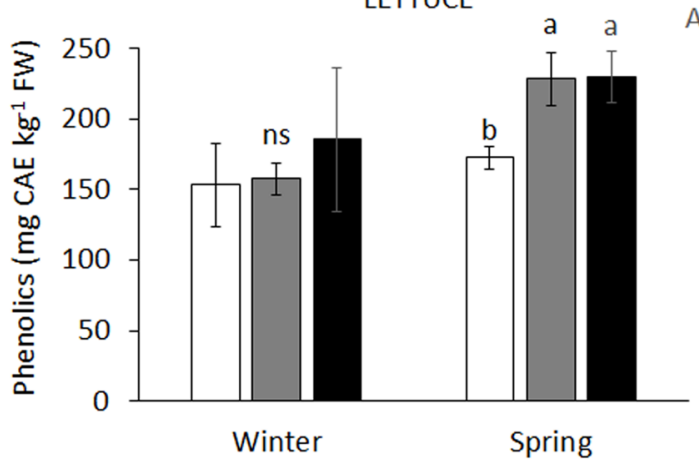

WATERCRESS

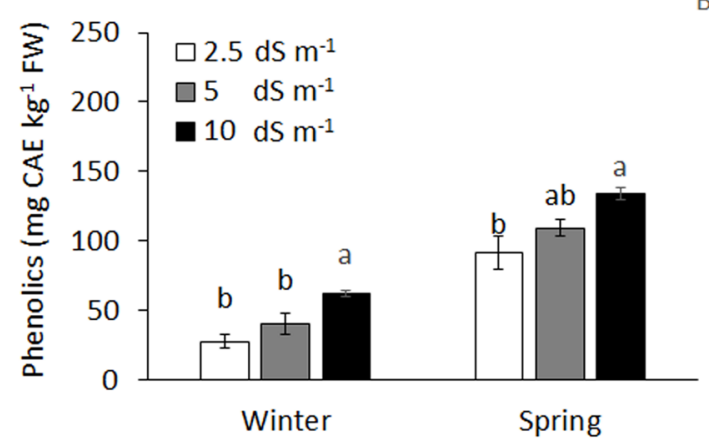

Fig. 5. Effect of salinity $\left(2.5,5\right.$ and $\left.10 \mathrm{dS} \mathrm{m}^{-1}\right)$ on leaf phenolics $\left(\mathrm{mg} \mathrm{CAE} \mathrm{kg}^{-1} \mathrm{FW}\right)$ of lettuce (A) and watercress (B). Mean values \pm SE. Different letters indicate significant differences at $p \leq 0.05$, according to LSD test.

No differences were observed among most of the parameters examined in the sensory evaluation (Table 2), except "strange taste", which was significantly higher in watercress grown under $10 \mathrm{dS} \mathrm{m}^{-1}$ than in plants grown in control conditions in the spring cycle. 
Table 2. Sensory quality evaluation of lettuce and watercress grown in floating system in spring cycle as a consequence of nutrient solution salinity $\left(2.5,5\right.$ and $\left.10 \mathrm{dS} \mathrm{m}^{-1}\right)$ and stored for 7 days at $5^{\circ} \mathrm{C}$, as reported by 11 independent panellists. Different letters indicate significant differences at $p \leq 0.05$.

\begin{tabular}{|c|c|c|c|c|c|c|c|c|c|c|c|c|c|c|c|}
\hline \multirow[b]{2}{*}{ Lettuce } & \multirow[b]{2}{*}{2.5} & \multicolumn{2}{|c|}{$\begin{array}{l}\text { Strange } \\
\text { colour }\end{array}$} & \multicolumn{2}{|c|}{ Browning } & \multicolumn{2}{|c|}{ Dehydration } & \multicolumn{2}{|c|}{$\begin{array}{l}\text { Strange } \\
\text { aromas }\end{array}$} & \multicolumn{2}{|c|}{ Strange taste } & \multicolumn{2}{|c|}{$\begin{array}{c}\text { Visual } \\
\text { appearance }\end{array}$} & \multicolumn{2}{|c|}{$\begin{array}{l}\text { Global } \\
\text { quality }\end{array}$} \\
\hline & & 1.71 & - & 2.00 & - & 2.57 & - & 1.14 & - & 1.57 & - & 6.42 & - & 6.71 & - \\
\hline & 10 & 2.57 & - & 2.14 & - & 2.00 & - & 1.28 & - & 2.00 & - & 5.71 & - & 5.85 & - \\
\hline Watercress & 10 & 1.33 & - & 1.16 & - & 1.66 & - & 1.16 & - & 2.33 & $\mathrm{a}$ & 7.00 & - & 6.50 & - \\
\hline
\end{tabular}

\section{Discussion}

\section{Plant growth and mineral uptake}

The decrease in root diameter as a response to salt conditions has previously been reported in cotton (Zhang et al. 2014). However, the activation of such a response was not always evident in mildly salt-stressed lettuce plants (Lucini et al. 2015), as it is generally dependent on the magnitude of the stress perceived by the crop. On the other hand, a $\mathrm{Cl}^{-}$toxicity effect in leaves was assumed in watercress exposed to salinity (Figs. $2 \mathrm{E}$ and $2 \mathrm{~F}$ ). This was especially true in spring when, due to the higher temperatures (Table 1), plant growth was higher (Fig. 2D), resulting in greater water uptake and a consequent increase in $\mathrm{Cl}^{-}$accumulation (Fig. 2E). Unexpectedly, the lettuce yield response to salinity (Fig. 2A) differed from previous results reported in the literature (Ünlükara et al. 2008), where increasing salinity in a similar range $\left(0.7\right.$ to $\left.7 \mathrm{dS} \mathrm{m}^{-1}\right)$ linearly reduced yield (about $12 \%$ reduction for each additional $\mathrm{dS} \mathrm{m}^{-1}$ in the nutrient solution). In the 1990s, the salinity threshold beyond which yield is reduced in lettuce was set at $2.7 \mathrm{dS} \mathrm{m}^{-1}$ (De Pascale and Barbieri 1995), although this applies to standard growing conditions and may vary in response to the peculiar environmental features in which plants are grown. In the same study, however, lettuce was described as a relatively tolerant species compared with other winter vegetables (e.g. fennel), with a yield decrease slope of about $5.8 \%$ per $\mathrm{dS} \mathrm{m}^{-1}$.

The increase in $\mathrm{Na}^{+}$and $\mathrm{Cl}^{-}$concentrations as the result of $\mathrm{NaCl}$-salinity is a common and expected response, which has been reported for both lettuce (Eraslan et al. 2010) and watercress (Kaddour et al. 2013). Nonetheless, beyond the toxicity effect of chloride on the cell structure, plant $\mathrm{Na}^{+}$accumulation in shoots may result in reduced growth due to the impaired absorption of important nutritional ions (e.g. $\mathrm{K}^{+}$or $\mathrm{Ca}^{2+}$ ). In the studied species, differences in ion selectivity under salinity were evident. Lettuce mainly showed a reduced $\mathrm{Ca}^{2+}$ content (Fig. 3C), (Neocleous et al. 2014) but unchanged $\mathrm{K}^{+}$uptake, resulting in maintained growth rates independently of salinity. The capacity of this species to preserve $\mathrm{K}^{+}$uptake in the face of salinity was previously documented (Kohler et al. 2009) and may explain the absence of a visible salt-induced yield reduction. As regards $\mathrm{Ca}^{2+}$, salinity not only reduced the accumulation of this ion in leaf tissue as a result of the accumulation of $\mathrm{Na}^{+}$, but also as a consequence of its reduced mobility and transport to shoots due to the lower water uptake (Coskun et al. 2013, Osakabe et al. 2014). While reduced water uptake impaired watercress growth in saline conditions (Fig. 3D), the $\mathrm{Ca}^{2+}$ reduction was linearly correlated with $\mathrm{Na}^{+}$accumulation in shoots (Fig. 3F). Nonetheless, a consistent 5 -fold reduction in $\mathrm{K}^{+}$ uptake in $10 \mathrm{dS} \mathrm{m}^{-1}$ treated plants (data not shown) resulted in a dramatic increase in the $\mathrm{Na}^{+}: \mathrm{K}^{+}$ratio in winter grown watercress (Fig. $3 \mathrm{E}$ ), suggesting that in milder climatic conditions the plant counterbalanced a reduced $\mathrm{Ca}^{2+}$ uptake by modulating the accumulation of $\mathrm{K}^{+}$. Similar responses have previously been observed in other Brassicaceae, such as cabbage (Lee et al. 2013) and canola (Tunçtürk et al. 2013), but also Arabidopsis thaliana (Kaddour et al. 2013), where at least 35 genes were confirmed as modulating $\mathrm{K}^{+}$uptake and transport in response to salinity (Qi and Spalding 2004). Any changes in the status of this cation (particularly strong $\mathrm{K}^{+}$deficiency) will affect growth by limiting cell expansion and inhibiting photosynthetic processes (Lebaudy et al. 2007). In previous studies, watercress was shown to efficiently maintain a fairly constant $\mathrm{Na}^{+}: \mathrm{K}^{+}$ratio up to the application of $100 \mathrm{mM} \mathrm{NaCl}$ (Kaddour et al. 2013), while any further increase in salinity would cause a rapid growth in the index comparable to that observed in our results obtained during the winter cycle. 


\section{Quality of baby-leaf vegetables exposed to salt stress}

Salinity caused a rise in the leaf concentrations of sodium of up to 1800 and $3000 \mathrm{mg} \mathrm{kg}^{-1}$ in lettuce and watercress, respectively (Fig. 3). Salt recognition thresholds are strongly influenced by consumption habits (Hayes et al. 2010) and have been shown to range between around 600 (Hatae et al. 2009) and 1300 (Lucas et al. 2011, Mitchell et al. 2012) $\mathrm{mg} \mathrm{kg}^{-1}$, being generally lower in female subjects, who are typically used to a lower dietary salt intake. Accordingly, the highest salinity level tested could result in an appreciable salty taste of the product, as was suggested by the sensory panel test analysis in watercress, which mentioned a "strange" taste (Table 2). Nonetheless, comparative studies between salt-rich and salt-poor foods found that no significant effect on consumer acceptability and purchase intent scores are generally related to product salinity (Mitchell et al. 2012).

The observed phenolics concentrations were in line with previous values reported in the literature (Conesa et al. 2015). The increased phenolics concentration in salinized crops in winter (watercress only) and spring (both crops) (Fig. 5) is consistent with the activation of a biochemical response to salinity as previously documented in both lettuce (Pérez-López et al. 2015) and watercress (Kaddour et al. 2013). Although the ion increase in the leaf tissue could also be associated with negative health effects (e.g. hypertension risk associated with salt intake - He and MacGregor 2009, Soetan et al. 2010), the proper management of salt concentration in the nutrient solution has been proven to provide an effective tool for improving leafy vegetable quality (Gruda 2009). More specifically, the proper management of salts in the nutrient solution in floating systems could be considered an effective tool to improve quality and nutritional aspects (Colla et al. 2013).

In spring, the nitrate concentration in lettuce plants was higher than the values observed in winter. Nitrate accumulation in plants is generally associated with a direct relationship with nitrogen availability (Kerbirou et al. 2013), and with an inverse relationship with water chloride concentration (Neocleous et al. 2014) and nitrate-reductase activity (Pinto et al. 2014). The enzymatic activity of nitrate reductase is known to be modulated by light access (Pinto et al. 2014), which, in lettuce, presented similar values in winter and spring cycles $\left(9.6 \mathrm{~mol} \mathrm{~m}^{-2} \mathrm{~s}^{-1}\right.$, Table 1). Consistently, while no seasonal effect could be observed in the overall nitrate concentration in lettuce, $\mathrm{Cl}^{-}$salinity was responsible for the decreased nitrate content compared with measurements made in control conditions in both growing cycles (Fig. 4B). The same was observed in watercress, although the detected differences in the overall light integral (7.3 vs. $8.4 \mathrm{~mol} \mathrm{~m}^{-2} \mathrm{~s}^{-1}$ in winter vs. spring, respectively, Table 1) resulted in a much greater nitrate content in winter compared with spring-grown plants (Fig. 4C). Furthermore, the difference in both average $\left(+5^{\circ} \mathrm{C}\right)$ and maximum $\left(+3^{\circ} \mathrm{C}\right)$ temperatures was higher (Table 1$)$ in spring than in winter. It has recently been shown how genes responsible for modulating nitrate reductase activity in Arabidopsis are promoted when temperatures increases from 22 to $28{ }^{\circ} \mathrm{C}$ (Wang et al. 2013). The lower nitrate values consistently, observed in the nitrate content in spring may be a result of both light access and increased temperatures, with the subsequent activation of nitrate reductase (Fig. 4). Given that differences in nitrate accumulation in response to salinity have been also shown to depend on a range of other factors (e.g. cultivar-Escobar-Gutierrez et al. 2002, Burns et al. 2011-; nitrogen quantity and form-Santamaria et al. 1998, Konstantopoulou et al. 2010, M'hamdi et al. 2014 or harvest time-Orsini and De Pascale 2006), further experiments should address complementary strategies for reducing nitrates in leafy vegetables.

\section{Conclusions}

The present work provides a comprehensive vision of the elements involved in the salt stress response of watercress in different growing seasons. Overall, despite the observed yield reduction in the presence of salinity, the nutritional quality of the harvested product was improved both in terms of nutritional (increased phenolics) and anti-nutritional (reduced nitrate) compounds. These effects were maximized in the winter cycle, when detrimental effects on yield were also lower. No differences in the sensory evaluation were associated with salinity in the studied

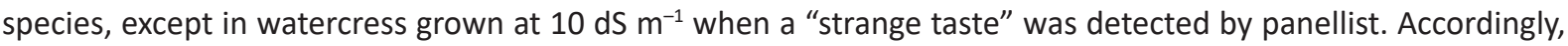
moderately saline water may be used to obtain watercress and lettuce plants with improved nutraceutical value for the baby-leaf market sector.

\section{Acknowledgements}

This work was financed by the Spanish project MICINN-FEDER AGL2010-17680. The work was partially carried out in the Instituto de Biotecnología Vegetal (IBV) of Universidad Politécnica de Cartagena (Spain). 


\section{References}

Acosta, J.A., Faz, A., Jansen, B., Kalbitz, K. \& Martínez-Martínez, S. 2011. Assessment of salinity status in intensively cultivated soils under semiarid climate, Murcia, SE Spain. Journal of Arid Environment 75: 1056-1066.

Amr, A. \& Hadidi, N. 2001. Effect of cultivar and harvest data on nitrate $\left(\mathrm{NO}_{3}\right)$ and nitrite $\left(\mathrm{NO}_{2}\right)$ content of selected vegetables grown under open field and greenhouse conditions in Jordan. Journal of Food Composition and Analysis 14: 59-67.

Brecht, J.K., Saltveit, M.E., Talcott, S.T., Schneider, K.R., Felkey, K. \& Bartz, J.A. 2004. Fresh-cut vegetables and fruits. Horticultural Reviews 30: 185-246.

Burns, I. G., Zhang, K., Turner, M. K., Meacham, M., Al-Redhiman, K., Lynn, J., Broadley, M.R., Hand, P. \& Pink, D. 2011. Screening for genotype and environment effects on nitrate accumulation in 24 species of young lettuce. Journal of the Science of Food and Agriculture 91: 553-562.

Colla, G., Rouphael, Y., Cardarelli, M., Svecova, E., Rea, E. \& Lucini, L. 2013. Effects of saline stress on mineral composition, phenolic acids and flavonoids in leaves of artichoke and cardoon genotypes grown in floating system. Journal of the Science of Food and Agriculture 93: 1119-1127.

Conesa, E., Fernández, J.A., Niñirola, D. \& Egea-Gilabert, C. 2015. Nutrient solution aeration and growing cycles affect quality and yield of fresh-cut baby leaf red lettuce. Agricultural and Food Science 24: 313-322.

Coskun, D., Britto, D.T., Jean, Y.K., Kabir, I., Tolay, I., Torun, A.A. \& Kronzucker, H.J. 2013. K+ efflux and retention in response to NaCl stress do not predict salt tolerance in contrasting genotypes of rice (Oryza sativa L.). PloS One 8: e57767.

De Pascale, S. \& Barbieri, G. 1995. Effects of soil salinity from long-term irrigation with saline-sodic water on yield and quality of winter vegetable crops. Scientia Horticulturae 64: 145-157.

Ekholm, P., Granlund, K., Kauppila, P., Mitikka, S., Niemi, J., Rankinen, K., Räike A. \& Räsänen, J. 2007. Influence of EU policy on agricultural nutrient losses and the state of receiving surface waters in Finland. Agricultural and food science 16: 282-300.

Eraslan, F., Inal, A., Savasturk, O. \& Gunes, A. 2010. Changes in antioxidative system and membrane damage of lettuce in response to salinity and boron toxicity. Scientia Horticulturae 114: 5-10.

Escobar-Gutierrez, A.J., Burns, I.G., Lee, A. \& Edmondson, R.N. 2002. Screening lettuce cultivars for low nitrate content during summer and winter production. The Journal of Horticultural Science and Biotechnology 77: 232-237.

Gill, C.I.R., Halder, S., Boyd, L.A., Bennett, R., Whiteford, J., Butler, M., Pearson, J.R., Bradbury, I. \& Rowland, I.R. 2007. Watercress supplementation in diet reduces lymphocyte DNA damage and alters blood antioxidant status in healthy adults. The American Journal of clinical Nutrition 85: 504-510.

GRIN (Germplasm Resources Information Network) 2012. National Germplasm Resources Laboratory, Beltsville, Maryland. http:// www.ars-grin.gov/cgi-bin/npgs/html/taxon.pl?25072. (Accessed 08 May 2016).

Gruda, N. 2009. Does soilless culture have an influence on product quality of vegetables? Journal of Applied Botany and Food Quality 82: 141-147.

Hatae, K., Takeutchi, F., Sakamoto, M., Ogasawara, Y. \& Akano, H. 2009. Saltiness and acidity: Detection and recognition thresholds and their interaction near the threshold. Journal of Food Science 74: S147-S153.

Hayes, J.E., Sullivan, B.S. \& Duffy, V.B. 2010. Explaining variability in sodium intake through oral sensory phenotype, salt sensation and liking. Physiology \& Behaviour 100: 369-380.

He, F.J. \& MacGregor, G.A. 2009. A comprehensive review on salt and health and current experience of worldwide salt reduction programmes. Journal of human hypertension 23: 363-384.

Kaddour, R., Draoui, E., Baâtour, O., Mahmoudi, H., Tarchoun, I., Nasri, N. \& Lachaâl, M. 2013. Assessment of salt tolerance of Nasturtium officinale R. Br. using physiological and biochemical parameters. Acta Physiologiae Plantarum 35: 3427-3436.

Kader, A.A. 2008. Flavor quality of fruits and vegetables. Journal of the Science of Food and Agriculture 88: 1863-1868.

Kerbiriou, P.J., Stomph, T.J., Van Der Putten, P.E.L., Van Bueren, E.L. \& Struik, P.C. 2013. Shoot growth, root growth and resource capture under limiting water and N supply for two cultivars of lettuce (Lactuca sativa L.). Plant and Soil 371: 281-297.

Kimura, M. \& Rodriguez-Amaya, D.B. 2003. Carotenoid composition of hydroponic leafy vegetables. Journal of Agricultural Food Chemistry 51: 2603-2607.

Kohler, J., Hernández, J.A., Caravaca, F. \& Roldán, A. 2009. Induction of antioxidant enzymes is involved in the greater effectiveness of a PGPR versus AM fungi with respect to increasing the tolerance of lettuce to severe salt stress. Environmental and Experimental Botany 65: 245-252.

Konstantopoulou, E., Kapotis, G., Salachas, G., Petropoulos, S.A., Karapanos, I.C., \& Passam, H.C. 2010. Nutritional quality of greenhouse lettuce at harvest and after storage in relation to $\mathrm{N}$ application and cultivation season. Scientia Horticulturae 125: 93 -e1-e5.

Lara, L.J., Egea-Gilabert, C., Niñirola, D., Conesa, E. \& Fernández, J.A. 2011. Effect of aeration of the nutrient solution on the growth and quality of purslane (Portulaca oleracea). The Journal of Horticultural Science and Biotechnology 86: 603-610.

Lebaudy, A., Véry, A.A. \& Sentenac, H. 2007. $\mathrm{K}^{+}$channel activity in plants: genes, regulations and functions. FEBS letters 581 : 2357-2366.

Lee, J., Park, I., Lee, Z.W., Kim, S.W., Baek, N., Park, H.S. \& Kim, H. 2013. Regulation of the major vacuolar $\mathrm{Ca}^{2+}$ transporter genes, by intercellular $\mathrm{Ca}^{2+}$ concentration and abiotic stresses, in tip-burn resistant Brassica oleracea. Molecular Biology Reports 40: 177-188.

Lucas, L., Riddell, L., Liem, G., Whitelock, S. \& Keast R. 2011. The influence of sodium on liking and consumption of salty food. Journal of Food Science 76: S72-S76.

Lucini, L., Rouphael, Y., Cardarelli, M., Canaguier, R., Kumar, P. \& Colla, G. 2015. The effect of a plant-derived biostimulant on metabolic profiling and crop performance of lettuce grown under saline conditions. Scientia Horticulturae 182: 124-133. 
M'hamdi, M., Boughattas, I., Rouhou, H.C., Souhli, E. \& Bettaieb, T. 2014. Effect of different levels of nitrogen fertilizer on morphological and physiological parameters and nitrates accumulation of lettuce cultivars (Lactuca sativa L.). Research in Plant Biology 4:4.

Mitchell, M., Brunton, N.P. \& Wilkinson, M.G. 2012. The influence of salt taste threshold on acceptability and purchase intent of reformulated reduced sodium vegetable soups. Food Quality and Preference 28: 356-360.

Neocleous, D., Koukounaras, A., Siomos, A.S. \& Vasilakakis, M. 2014. Assessing the salinity effects on mineral composition and nutritional quality of green and red "baby" lettuce. Journal of Food Quality 37: 1-8.

Niñirola, D., Fernández, J.A., Conesa, E., Martínez, J.A. \& Egea-Gilabert, C. 2014. Combined effects of growth cycle and different levels of aeration in nutrient solution on productivity, quality, and shelf life of watercress (Nasturtium officinale R. Br.) plants. HortScience 49: 567-573.

Orsini, F. \& De Pascale, S. 2006. Daily variation in leaf nitrate content of two cultivars of hydroponically grown basil. Acta Horticulturae 747: 203-210.

Osakabe, Y., Yamaguchi-Shinozaki, K., Shinozaki, K. \& Tran, L.S.P. 2014. ABA control of plant macroelement membrane transport systems in response to water deficit and high salinity. New Phytologist 202: 35-49.

Pérez-López, U., Miranda-Apodaca, J., Lacuesta, M., Mena-Petite, A. \& Muñoz-Rueda, A. 2015. Growth and nutritional quality improvement in two differently pigmented lettuce cultivars grown under elevated $\mathrm{CO}_{2}$ and/or salinity. Scientia Horticulturae 195: $56-66$.

Perez-Sirvent, C., Martınez-Sanchez,M.J., Vidal, J. \& Sanchez, A. 2003. The role of low-quality irrigation water in the desertification of semi-arid zones in Murcia, SE Spain. Geoderma 113: 109-125.

Pignata, G., Niñirola, D., Casale, M., Lo Turco, P.E., Egea-Gilabert, C., Fernández, J.A. \& Nicola, S. 2016. Inherent quality and safety of watercress grown in a floating system using Bacillus subtilis. The Horticulturae Journal 85: 148-153.

Pinto, E., Fidalgo, F., Teixeira, J., Aguiar, A.A. \& Ferreira, I.M. 2014. Influence of the temporal and spatial variation of nitrate reductase, glutamine synthetase and soil composition in the N species content in lettuce (Lactuca sativa). Plant Science 219: 35-41.

Qi, Z. \& Spalding, E.P. 2004. Protection of plasma membrane $\mathrm{K}^{+}$transport by the salt overly sensitive1 $\mathrm{Na}^{+}-\mathrm{H}^{+}$antiporter during salinity stress. Plant Physiology 136: 2548-2555.

Rodríguez-Hidalgo, S., Artés-Hernández, F., Gómez, P., Artés, F. \& Fernández, J.A. 2009. Quality changes on minimally processed purslane baby leaves growth under floating trays system. Acta Horticulturae 877: 641-648.

Santamaria, P., Elia, A., Parente, A. \& Serio, F. 1998. Fertilization strategies for lowering nitrate content in leafy vegetables: chicory and rocket salad cases. Journal of plant Nutrition 21: 1791-1803.

Scuderi, D., Restuccia, C., Chisari, M., Barbagallo, R.N., Caggia, C. \& Giuffrida, F. 2011. Salinity of nutrient solution influences the shelf-life of fresh-cut lettuce grown in floating system. Postharvest Biology and Technology 59: 132-137.

Shahrokhi, N., Hadad, M.K., Keshavarzi, Z. \& Shabani, M. 2009. Effect of aqueous extract of watercress on glucose and lipid plasma in streptozotocin induced diabetic rats. Pakistan Journal of Physiology 5: 6-10.

Soetan, K.O., Olaiya, C.O. \& Oyewole, O.E. 2010. The importance of mineral elements for humans, domestic animals and plants-A review. African Journal of Food Science 4: 200-222.

Soliva-Fortuny, R.C. \& Martìn-Belloso, O. 2003. New advances in extending the shelf-life of fresh-cut fruits: a review. Trends in Food Science \& Technology 14: 341-353.

Tarazona-Díaz, M.P., Viegas, J., Moldao-Martins, M. \& Aguayo, E. 2011. Bioactive compounds from flesh and by-product of freshcut watermelon cultivars. Journal of the Science of Food and Agriculture 91: 805-812.

Tomás-Callejas, A., Martínez-Hernández, G.B., Artés, F. \& Artés-Hernández, F. 2011. Neutral and acidic electrolyzed water as novel sanitizers on fresh-cut mizuna baby leaves. Effects on safety and quality attributes. Postharvest Biology and Technology 59: 298-306.

Tomasi, N., Pinton, R., Dalla Costa, L., Cortella, G., Terzano, R., Mimmo, T., Scampicchio, M. \& Cesco, S. 2015. New 'solutions' for floating cultivation system of ready-to-eat salad: A review. Trends in Food Science and Technology 46: 267-276.

Tunçtürk, M., Tunçtürk, R., Yildirim, B. \& Çiftçi, V. 2013. Effect of salinity stress on plant fresh weight and nutrient composition of some Canola (Brassica napus L.) cultivars. African Journal of Biotechnology 10: 1827-1832.

Ünlükara, A., Cemek, B., Karaman, S. \& Erşahin, S. 2008. Response of lettuce (Lactuca sativa var. Crispa) to salinity of irrigation water. New Zealand Journal of Crop and Horticultural Science 36: 265-273.

Verhoeven, D.T., Verhagen, H., Goldbohm, R.A., van den Brandt, P.A. \& van Poppel, G. 1997. A review of mechanisms underlying anticarcinogenicity by brassica vegetables. Chemico-Biological Interactions 103: 79-129.

Wang, H., Lu, Y., Liu, P., Wen, W., Zhang, J., Ge, X. \& Xia, Y. 2013. The ammonium/nitrate ratio is an input signal in the temperaturemodulated, SNC1-mediated and EDS1-dependent autoimmunity of nudt6-2 nudt7. The Plant Journal 73: 262-275.

Zhang, L., Ma, H., Chen, T., Pen, J., Yu, S. \& Zhao, X. 2014. Morphological and physiological responses of cotton (Gossypium hirsutum L.) plants to salinity. PloS One 9: e112807. 